J. Clin. Chem. Clin. Biochem.

Vol. 23, 1985, pp. 637-643

\title{
Isolation and Characterization of Porcine $\alpha_{1}$-Proteinase Inhibitor $\left.^{1}\right),{ }^{2}$ )
}

\section{Leukocyte Elastase-Inhibitor Complexes in Porcine Blood, I.}

\author{
By R. Geiger, Gisela Leysath and H. Fritz \\ Abteilung für Klinische Chemie und Klinische Biochemie (Leitung: Prof. Dr. H. Fritz) in der Chirurgischen \\ Klinik Innenstadt der Universität München
}

(Received March 18/June 20, 1985)

\begin{abstract}
Summary: $\alpha_{1}$-Proteinase inhibitor was purified from procine blood by ammonium sulphate and Cibachron Blue-Sepharose fractionation, ion exchange chromatography on DEAE-Cellulose, gel filtration on Sephadex G-25, and zinc chelating chromatography. Thus, an inhibitor preparation with a specific activity of 1.62 IU/mg protein (enzyme: trypsin; substrate: BzArgNan) was obtained. In sodium dodecyl sulphate gel electrophoresis one protein band corresponding to a molecular mass of $67.6 \mathrm{kDa}$ was found. On isoelectric focusing 6 protein bands with isoelectric points of $3.80,3.90,4.05,4.20,4.25$ and 4.45 were separated. The amino acid composition was determined. The association rate constants for the inhibition of various serine proteinases were measured.
\end{abstract}

\section{Isolierung und Charakterisierung des $\alpha_{1}$-Proteinaseinhibitors des Schweins Leukocyten- $\alpha_{1}$-Proteinaseinhibitor-Komplexe in Schweineblut, I.}

Zusammenfassung: $\alpha_{1}$-Proteinaseinhibitor wurde aus Schweineblut mittels Ammoniumsulfatfällung und Fraktionierung an Cibachron-Blau-Sepharose, Ionenaustauschchromatographie an DEAE-Cellulose, Gelfiltration an Sephadex G-25 und Zink-Chelat-Chromatographie isoliert. Die erhaltene Inhibitor-Präparation hatte eine spezifische Aktivität von 1,62 IU/mg Protein (Enzym: Trypsin; Substrat: BzArgNan). In der Natriumdodecylsulfat-Elektrophorese wurde eine Proteinbande mit einer dazugehörigen Molekülmasse von 67,6 kDa erhalten. In der isoelektrischen Fokussierung wurden 6 Proteinbanden mit isoelektrischen Punkten von 3,80, 3,90, 4,05, 4,20, 4,25 und 4,45 gefunden. Die Aminosäurezusammensetzung wurde bestimmt. Die Assoziationskonstanten für die Hemmung von verschiedenen Serinproteinasen wurden gemessen.

1) Abbreviations:

BzArgNan:

IEP:

Isoelectric point

IU:

Inhibitor units $(\mathrm{mIU}=$ mîlli-IU $)$

kDa:

kilo-Dalton

DValLeuLysNan:

$D$-valyl- $L$-leucyl- $L$-lysine- $p$-nitroanilide

Suc(Ala) ${ }_{3}$ Nan:

$\mathrm{N}^{\alpha}$-succinyl-( $L$-alanyl $)_{2}-L$-alanine-p-nitroanilide

MeOSuc(Ala) 2 ProValNan:

$\mathrm{N}^{\alpha}$-methoxysuccinyl-( $L$-alanyl $)_{2}-L$-prolyl- $L$-valine-p-

nitroanilide
TosGlyProArgNan:

$N^{\alpha}$-tosyl- $L$-glycyl- $L$-prolyl- $L$-arginine-p-nitroanilide

Suc(Ala) ${ }_{2}$ ProPheNan:

$\mathrm{N}^{\alpha}$-succinyl-( $L$-alanyl $)_{2}-L$-prolyl- $L$-phenylalanine-pnitroanilide

$\left(\mathrm{H}_{2} \mathrm{~N}_{2}\right)_{2} \mathrm{CNBzONp}$ :

$p$-nitrophenyl $p^{\prime}$-guanidobenzoate

2) Enzymes:

porcine trypsin (EC 3.4.21.4), bovine chymotrypsin (EC 3.4.21.1), bovine thrombin (EC 3.4.21.5), boar acrosin (EC 3.4.21.10), bovine plasmin (EC 3.4.21.7), porcine pancreatic elastase (EC 3.4.21.36), porcine leukocyte elastase (EC 3.4.21.37) from polymorphonuclear granulocytes. 


\section{Introduction}

$\alpha_{1}$-Proteinase inhibitor, formerly called $\alpha_{1}$-antitrypsin, is a glycoprotein and responsible for more than $90 \%$ of the trypsin and elastase inhibiting capacity of plasma or serum (1). The high concentration of this inhibitor in blood, interstitial fluid and mucous secretions and its broad inhibitory specificity towards proteinases $(2,3)$ reflects an important role in regulating physiological and/or preventing pathological processes in the organism.

In this connection, the pathological events of major interest are inflammatory processes (4) and bacterial sepsis with its most serious complication, septic shock. As demonstrated recently, $\alpha_{1}$-proteinase inhibitor complexes with and thereby inhibits lysosomal elastase, which is liberated by endotoxin-induced mechanisms from polymorphonuclear granulocytes (4).

Furthermore, it has been shown that an increase of the plasma levels of the elastase- $\alpha_{1}$-proteinase inhibitor complex in humans, as determined by enzyme immunoassay (5), is an early indication of the inflammatory response in septicaemia (6), multiple trauma (7) and rheumatoid arthritis (8). In view of the potential significance of the elastase- $\alpha_{1}$-proteinase inhibitor complex for the diagnosis of severe infections $(6,8)$ as well as for monitoring of the therapeutic effectiveness of inhibitors of lysosomal proteinases (9) development of suitable experimental animal models would be highly desirable. We have therefore isolated porcine $\alpha_{1}$-proteinase inhibitor and porcine leukocyte elastase $^{3}$ ) for the development of an elastase-inhibitor immunoassay, which permits the quantitation of lysosomal elastase liberation from pig polymorphonuclear granulocytes.

In this communication the purification of porcine $\alpha_{1}$-proteinase inhibitor is described and a detailed characterization of the purified inhibitor is given.

\section{Materials and Methods}

DEAE-Cellulose (DE-52) was from Whatman Chemicals, Clifton, U.S. A.

Sephadex G-75 and chelating Sepharose were from Pharmacia Fine Chemicals AB, Uppsala, Sweden.

BzArgNan, porcine trypsin and porcine pancreatic elastase were from Merck, Darmstadt.

Ampholine ${ }^{\circledR}$ 2-11 and ampholine 2-6 were from LKB, Bromma, Sweden. 3) Geiger, R., Junk, A. \& Jochum, M., this journal, in prepa-
ration
Bovine thrombin and chymotrypsin, bovine plasmin and TosGlyProArgNan were from Boehringer Mannheim, Mannheim.

Boar acrosin was kindly provided by $W$. Müller-Esterl, Munich.

Porcine leukocyte elastase was isolated according to Geiger et al. $\left.{ }^{3}\right)$.

Antiserum against porcine plasma was from Miles Laboratories, Ltd., Frankfurt.

Cibachron-Blue-Sepharose was syntheșized according to Travis \& Johnson (10)

Human $a_{1}$-proteinase inhibitor was from Behringwerke AG, Marburg/Lahn.

Suc(Ala) ${ }_{3}$ Nan, MeOSuc(Ala) $)_{2}$ ProvValNan and $\operatorname{Suc}(A l a)_{2}$ ProPheNan were from Novabiochem AG, Läufelfingen, Switzerland.

DValLeuLysNan was a gift from Kabi, Mölndal, Sweden.

\section{Starting material}

Porcine blood was collected from healthy pigs in the slaughter house of Munich in bottles containing sodium citrate in a final concentration of $3.8 \mathrm{~g} / \mathrm{l}$ to prevent coagulation. The blood samples were separated from blood cellis by centrifugation $(1800 \mathrm{~g})$ for $30 \mathrm{~min}$ and the supernatant plasma was used for the isolation of $\alpha_{1}$-proteinase inhibitor.

\section{Preparation of the zinc chelate column}

One hundred millilitres of chelating Sepharose 6B were washed on a sintered glass filter (G3) using 1.51 dist. water. The Sepharose was then added to a glass column $(100 \cdot 1 \mathrm{~cm})$ and loaded with zinc ions at $4^{\circ} \mathrm{C}$ by pumping through $200 \mathrm{ml}$ of a zinc chloride solution $(5 \mathrm{~g} / \mathrm{l})$. Thereafter the column was washed free of unbound zinc with distilled water and equilibrated with $0.05 \mathrm{~mol} / \mathrm{l}$ phosphate buffer $\left(\mathrm{Na}_{2} \mathrm{HPO}_{4}\right)$, pH 8.0 , containing $0.15 \mathrm{~mol} / \mathrm{l}$ soldium chloride.

\section{Activity and inhibition measurements}

The activity and molarity of trypsin used for the determination of the inhibitory activity of $a_{1}$-proteinase inhibitor was measured by titration with $\left(\mathrm{H}_{2} \mathrm{~N}_{2}\right)_{2} \mathrm{CNBzONp}$ according to Chase \& Shaw (10). Porcine trypsin used for the tests had an activity of $5.4 \mathrm{U} / \mathrm{mg}$ protein (substrate: BzArgNan). Inhibitory activity of $\alpha_{1}$-proteinase inhibitor was measured as described by Fritz et al. (11). Porcine trypsin and BzArgNan were used in the assay. The activities of chymotrypsin, thrombin, plasmin, acrosin, pancreatic elastase and leukocyte elastase, and their inhibition by $\alpha_{1}$-proteinase inhibitor were determined as described formerly $(13-17)$. Porcine leukocyte elastase activity was measured using the following procedure (wavelength: $405 \mathrm{~nm} ; 25^{\circ} \mathrm{C}$; volume: $\left.1 \mathrm{ml} ; \varepsilon=1020 \mathrm{~m}^{2} \cdot \mathrm{mol}^{-1} ;(30)\right): 0.98 \mathrm{ml} 2.14 \mathrm{mmol} / 1$ MeOSuc(Ala) $)_{2}$ ProValNan in $0.1 \mathrm{~mol} / 1$ HEPES buffer, $\mathrm{pH} 7.5$, containing $0.5 \mathrm{~mol} / 1$ sodium chloride were incubated at $25^{\circ} \mathrm{C}$ for $5 \mathrm{~min}$. Thereafter $0.02 \mathrm{ml}$ elastase solution was added and the increase in absorbance per minute was read for 5 minutes. Association rate constants were measured and calculated according to Beatty, Bieth \& Travis (18).

\section{Electrophoresis}

Coomassie RTM Blue G (Serva, Heidelberg, FRG) was used for protein staining.

Polyacrylamide gel electrophoresis in the presence of sodium dodecyl sulphate was performed according to Weber \& Osborne (19).
: 
$\alpha_{1}$-Proteinase inhibitor was submitted to electrofocusing in polyacrylamide gels $(t=50 \mathrm{~g} / \mathrm{l}, \mathrm{C}=30 \mathrm{~g} / \mathrm{l}$, containing $60 \mathrm{ml} / \mathrm{l}$ Ampholine ${ }^{\top} 2-11$, or $60 \mathrm{ml} / \mathrm{l}$ Ampholine ${ }^{\oplus}$ 2-6) according to Righetti \& Drysdale (20).

Isoelectric point standards from Serva (Heidelberg, FRG) were used as markers.

Immunoelectrophoresis and rocket immunoclectrophoresis were performed as described in 1.c. (21).

\section{Molecular mass determinations}

Molecular mass determinations were performed by polyacrylamide gel electrophoresis. Molecular mass standards from BioRad (Richmond, California) were used as markers.

\section{Protein determination}

Protein concentration was determined according to Folin \& Ciocalteau (22), and by quantitative amino acid analysis. For protein determination according to Folin \& Ciocalteau, human $\alpha_{1}$-proteinase inhibitor served as a reference standard.

\section{Amino acid analysis}

For amino acid analysis samples were hydrolysed in vacuo at $110^{\circ} \mathrm{C}$ with $5.7 \mathrm{~mol} / 1 \mathrm{HCl}$ for $24 \mathrm{~h}$ and analysed with a Durrum D 500. The $\mathrm{N}$-terminal amino acid residues were determined by Edman degradation (23). The phenylthiohydantoins were identified by an isocratic high performance liquid chromatography system (34).

\section{Results}

\section{Isolation procedure}

Purification of $\alpha_{1}$-proteinase inhibitor from porcine blood was achieved by the following procedure (tab. 1).

\section{Step 1}

One litre of porcine citrate plasma was fractionated at room temperature with ammonium sulphate. The precipitate obtained between 0.50 and 0.80 saturation was dissolved in $0.03 \mathrm{~mol} / \mathrm{l}$ phosphate buffer $\left(\mathrm{Na}_{2} \mathrm{HPO}_{4}\right)$, pH 6.7 and the solution dialysed for $24 \mathrm{~h}$ at $4{ }^{\circ} \mathrm{C}$ with several changes of the same buffer.

\section{Step 2}

The dialysed solution $(640 \mathrm{ml})$ was applied at room temperature to a Cibachron-Blue-Sepharose column $(100.5 \mathrm{~cm})$ equilibrated with phosphate buffer $(0.03$ $\left.\mathrm{mol} / 1 \mathrm{Na}_{2} \mathrm{HPO}_{4}\right) \mathrm{pH}$ 6.7. The flow rate was $100 \mathrm{ml} / \mathrm{h}$. The column was then washed with phosphate buffer, and $9 \mathrm{ml}$ fractions were collected. The fractions containing $\alpha_{1}$-proteinase inhibitor were eluted in the void volume, whereas porcine serum albumin remained tightly bound to the dye. The Cibachron-Blue Sepharose column was regenerated first with $0.5 \mathrm{~mol} / \mathrm{l}$ $\mathrm{KSCN}$ and subsequently by equilibration with 0.03 $\mathrm{mol} / \mathrm{l}$ phosphate buffer $\mathrm{pH} 6.7$.

\section{Step 3}

The $\alpha_{1}$-proteinase inhibitor-containing fractions from step 2 were combined $(1020 \mathrm{ml})$ and the $\mathrm{pH}$ was shifted to $\mathrm{pH} 6.5$ by addition of $2 \mathrm{~mol} / 1 \mathrm{HCl}$. The solution was applied at a rate of $30 \mathrm{ml} / \mathrm{h}$ at room temperature to a DEAE-cellulose column $(30 \cdot 2.5$ $\mathrm{cm}$; DE-52, Whatman Chemicals) equilibrated with phosphate buffer $\left(0.03 \mathrm{~mol} / \mathrm{l} \quad \mathrm{Na}_{2} \mathrm{HPO}_{4}\right) \mathrm{pH} 6.5$. Thereafter the column was washed with buffer until the eluate was free of protein $\left(A_{280}<0.005\right) . \alpha_{1}$ Proteinase inhibitor was eluted with a linear gradient of $\mathrm{NaCl}(0-0.2 \mathrm{~mol} / \mathrm{l})$ in phosphate buffer at the same flow rate. The gradient was formed from 1100 $\mathrm{ml}$ phosphate solution and $1100 \mathrm{ml}$ sodium chloride solution. Fractions of $10 \mathrm{ml}$ were collected (fig. 1).

Tab. 1. Purification of porcine $\alpha_{1}$-proteinase inhibitor. The data represent mean values of three different preparations.

\begin{tabular}{|c|c|c|c|c|c|c|}
\hline Step & Procedure and eluate therefrom & $\begin{array}{l}\text { Volume } \\
\text { (ml) }\end{array}$ & $\begin{array}{l}\text { Total } \\
\text { protein } \\
(\mathrm{mg})^{\mathrm{a}}\end{array}$ & $\begin{array}{l}\text { Total } \\
\text { inhibitory } \\
\text { activity } \\
\text { IU }^{\mathrm{b}}\end{array}$ & $\begin{array}{l}\text { Specific } \\
\text { inhibitory } \\
\text { activity } \\
\text { IU/mg }\end{array}$ & $\begin{array}{l}\text { Puri- } \\
\text { fication } \\
\text { factor }\end{array}$ \\
\hline & Porcine citrate plasma & 1000 & 53500 & 1610.0 & 0.030 & 1 \\
\hline 1 & $\begin{array}{l}\text { Ammonium sulphate fractionation } \\
\text { (after dialysis) }\end{array}$ & 640 & 14970 & 494.3 & 0.033 & 1.1 \\
\hline 2 & Cibachron-blue Sepharose & 1020 & 5783 & 429.4 & 0.074 & 2.5 \\
\hline 3 & DEAE-cellulose & 205 & 346 & 241.8 & 0.699 & 23.3 \\
\hline 4 & Sephadex G-75 & 180 & 270 & 239.6 & 0.887 & 29.6 \\
\hline 5 & Zinc chelate column & 22 & 16.7 & 27.0 & 1.616 & 53.9 \\
\hline
\end{tabular}

Protein concentration was determined according to Folin \& Ciocalteau (23).

b Inhibitory activity of $\alpha_{1}$-proteinase inhibitor was determined with trypsin and BzArgNan as substrate, cf. Methods. 


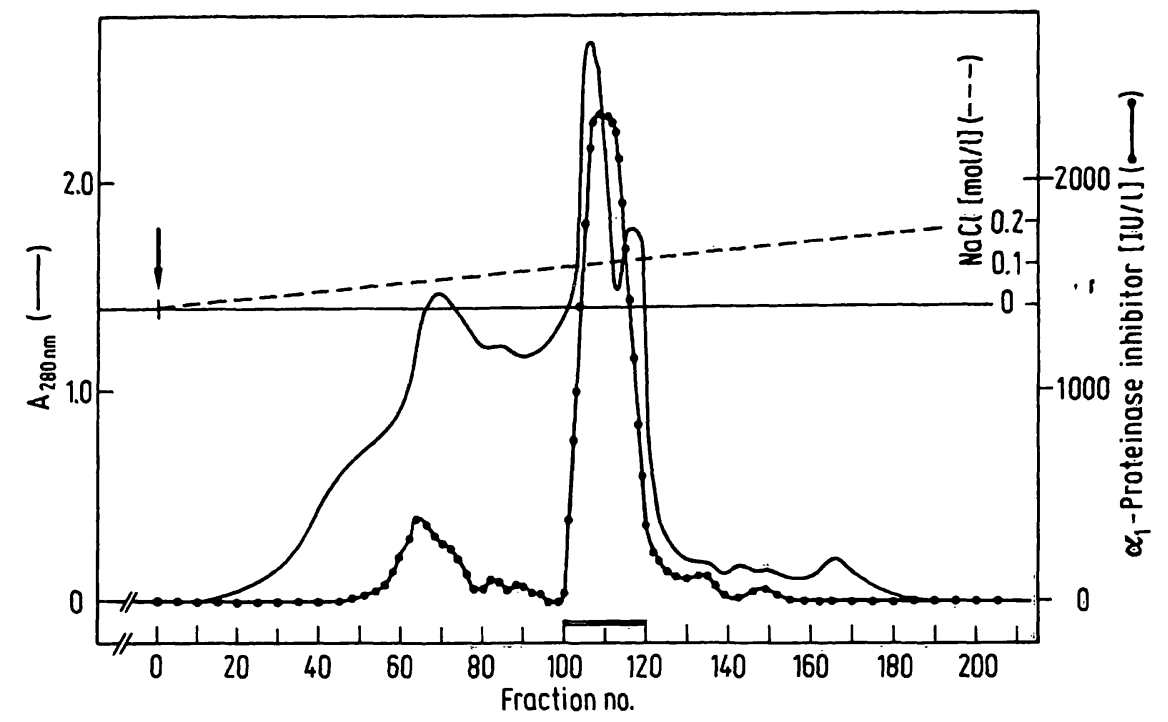

Fig. 1. Gradient elution chromatography of the $\alpha_{1}$-proteinase inhibitor-containing fractions from step 2 (cf. tab. 1) on DEAEcellulose. Experimental details are given in Results. $\alpha_{1}$-proteinase inhibitor inhibitory activity was measured by inhibition of porcine trypsin in the BzArgNan assay ( -0$)$, protein concentration is given as absorbance at $280 \mathrm{~nm}(\longrightarrow-$,$) , the$ concentration of the $\mathrm{NaCl}$ gradient is indicated $(---)$.

\section{Step 4}

The most active fractions from the preceding step were pooled $(205 \mathrm{ml})$ and concentrated by ultrafiltration (Amicon membrane YM 10). Thereafter the buffer was changed by repeated ultrafiltration to 0.05 mol/l phophate buffer $\left(\mathrm{Na}_{2} \mathrm{HPO}_{4}\right) \mathrm{pH} 8.0$ containing $0.15 \mathrm{~mol} / 1 \mathrm{NaCl}$. The resulting solution was applied at a rate of $11 \mathrm{ml} / \mathrm{h}$ to a Sephadex G-75 column (100 $.5 \mathrm{~cm}$ ) equilibrated with the same phosphate buffer.

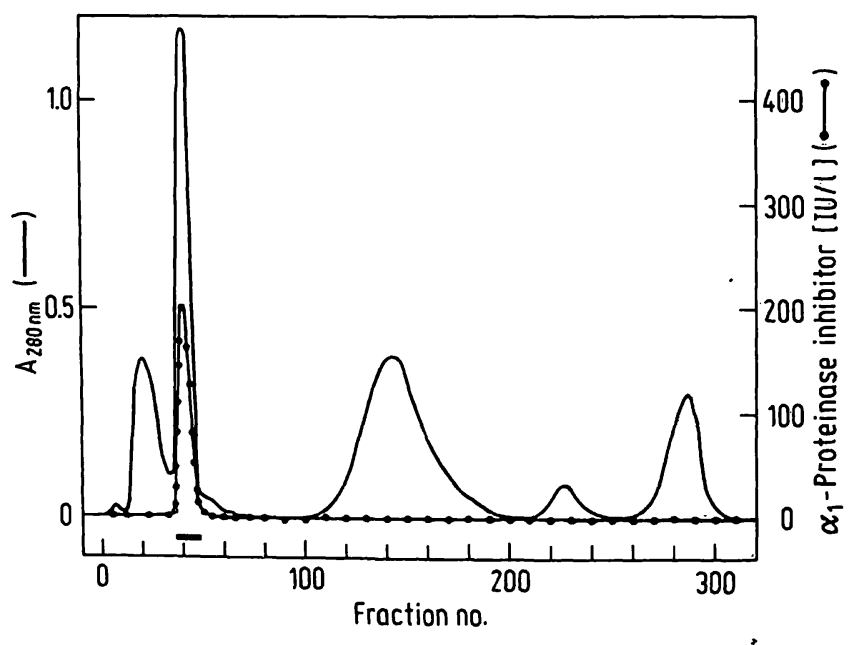

Fig. 2. Fractionation of porcine $\alpha_{1}$-proteinase inhibitor from step 4 (cf. Tabl. 1) on zinc chelate Sepharose. Experimental details are given in Results. $\alpha_{1}$-Proteinase inhibitor was assayed by inhibition of porcine trypsin in the $\mathrm{BzArgNan}$ assay $(\bullet-0)$, protein concentration is given as absorbance at $280 \mathrm{~nm}$ (- $\longrightarrow$. Phosphate buffer $(0.05 \mathrm{~mol} / \mathrm{l}, \mathrm{pH} 6.5$, containing $0.15 \mathrm{~mol} / \mathrm{l} \mathrm{NaCl})$ is used from the start for elution.
Fractions were combined and concentrated by ultrafiltration (Amicon membrane YM 10).

\section{Step 5}

The $\alpha_{1}$-proteinase inhibitor solution from step 4 (180 $\mathrm{ml})$ was applied to a zinc chelate column (100 . $1 \mathrm{~cm})$ equilibrated with $0.05 \mathrm{~mol} / \mathrm{l}$ phosphate buffer $\left(\mathrm{Na}_{2} \mathrm{HPO}_{4}\right)$ pH 8.0 containing $0.15 \mathrm{~mol} / 1 \mathrm{NaCl} . \alpha_{1}=$ Proteinase inhibitor was eluted as shown in figure 2 with $0.05 \mathrm{~mol} / \mathrm{l}$ phosphate buffer $\mathrm{pH} 6.5$ containing $0.15 \mathrm{~mol} / 1 \mathrm{NaCl}$. Fractions were collected in $1.5 \mathrm{ml}$ portions at a flow rate of $7.5 \mathrm{ml} / \mathrm{h}$.

The $\alpha_{1}$-proteinase inhibitor solution was divided into small portions and stored frozen at $-20^{\circ} \mathrm{C}$. At this temperature the inhibitor was stable for more than 12 months.

\section{Chemical and physical characteristics \\ Electrophoresis}

In polyacrylamide gel electrophoresis containing sodium dodecyl sulphate only one protein band appeared that corresponded to a molecular mass of 67.6 kDa (fig. 3).

On electrofocusing of $\alpha_{1}$-proteinase inhibitor samples in carrier ampholytes ( $\mathrm{pH}$ gradient from 2 to 11) several protein bands were found in positions around pH 4 (fig. $4 \mathrm{a}$ and b). Using a carrier ampholyte gradient from 2 to 6 , six protein bands with isoelectric points of $3.80,3.90,4.05,4.20,4.25$, and 4.45 were found (fig. $4 \mathrm{c}$ and $\mathrm{d}$ ). 


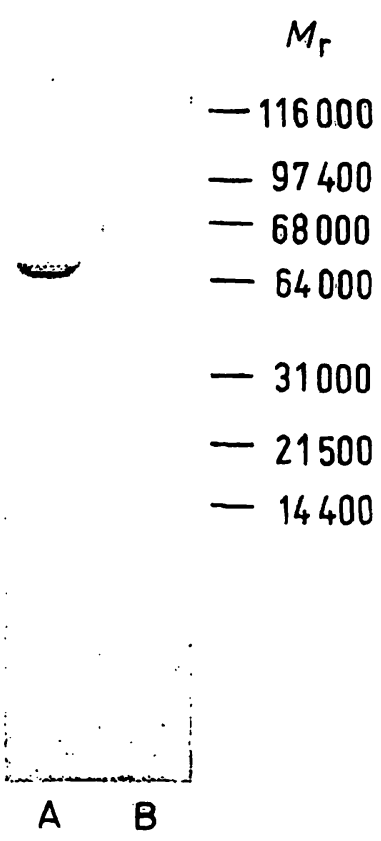

Fig. 3. Sodium dodecyl sulphate gel electrophoresis of porcine $\alpha_{1}$-proteinase inhibitor $(20 \mu \mathrm{g} ;$ gel A). For experimental details and $M_{\mathrm{r}}$ determination, see Methods. Molecular mass standards are present in gel B.

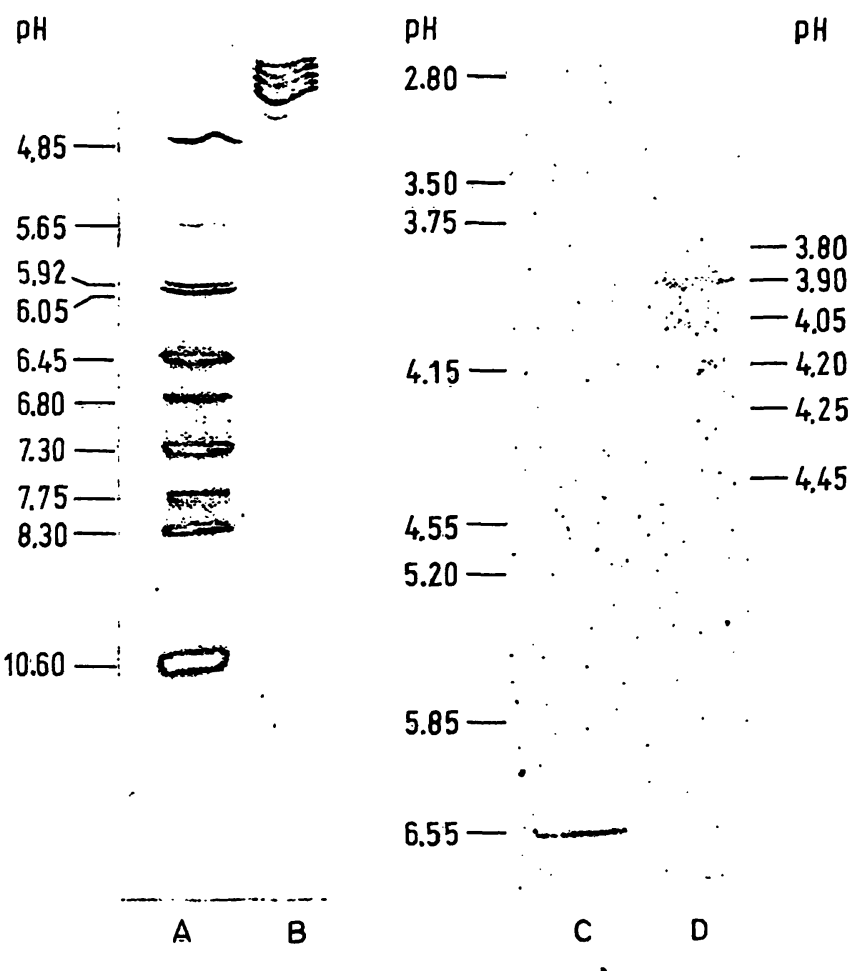

Fig. 4. Isoelectric focusing of porcine $\alpha_{1}$-proteinase inhibitor. $A$, protein standards (IEP from 4.85 to 10.6 ); $B$ and D, $10 \mu \mathrm{g}$ of porcine $\alpha_{1}$-proteinase inhibitor each; $C$, protein standards (IEP from 2.80 to 6.55 ). Isoelectric focusing was performed in ampholine 2 to 11 (A and B) and ampholine 2 to 6 (C and D). For details, see Methods.

\section{$N$-terminal residue}

Homogeneity of the $\alpha_{1}$-proteinase inhibitor preparation was checked further by analysis of the $\mathrm{N}$ - terminal amino acid residues. After one Edman degradation cycle, the phenylthiohydantoin derivatives of amino acids were identified by high performance liquid chromatography. After application of a sufficient amount of $\alpha_{1}$-proteinase inhibitor $(10 \mathrm{nmol})$ to the degradation cycle, no residue could be identified at all by HPLC (detection limit: $0.015 \mathrm{nmol}$ ). This result suggests that the amino terminal sequence of porcine $\alpha_{1}$-proteinase inhibitor, like that of human $\alpha_{1}$-proteinase inhibitor (25), starts with a glutamic acid residue, and that this glutamic residue is converted into pyroglutamic acid during the isolation procedure, which is a well known phenomenon.

\section{Amino acid composition}

The amino acid composition calculated from analyses of 3 Durrum runs and based on a molecular mass of $67.6 \mathrm{kDa}$ was determined. The data are listed in table 2 together with those of human $\alpha_{1}$-proteinase inhibitor for comparison.

Tab. 2. Amino acid compositions of human and porcine $\alpha_{1}$ proteinase inhibitor. The given values represent mol of residues per mol inhibitor.

\begin{tabular}{llc}
\hline Amino acid & \multicolumn{2}{c}{$\alpha_{1}$-Proteinase inhibitor } \\
& Porcine & Human $(9,27)$ \\
\hline Asp & 52 & 49 \\
Thr & 38 & 25 \\
Ser & 42 & 23 \\
Glu & 54 & 54 \\
Pro & 25 & 22 \\
Gly & 47 & 24 \\
Ala & 30 & 24 \\
Cys & n.d. & 1 \\
Val & 11 & 27 \\
Met & 8 & 8 \\
Ile & 20 & 18 \\
Leu & 48 & 50 \\
Tyr & 10 & 9 \\
Phe & 12 & 28 \\
His & 8 & 13 \\
Lys & 40 & 39 \\
Arg & 14 & 7 \\
Trp & n.d.b & 1 \\
\hline
\end{tabular}

a Extrapolated to hydrolysis time zero.

b Without tryptophan (n. d.: not detectable).

\section{Stability}

The inhibitor obtained by the given isolation procedure was stable in sodium chloride solution $(9 \mathrm{~g} / \mathrm{l})$ at $-20^{\circ} \mathrm{C}$ for more than 12 months. At $4^{\circ} \mathrm{C}$ no loss of inhibitory activity was observed for several months. To prevent bacterial growth and loss of activity due to bacterial proteinases, $2 \mathrm{~g} / \mathrm{l}$ of sodium azide should be added to the solution kept at $4{ }^{\circ} \mathrm{C}$. 
Tab. 3. Association rate constants $\mathrm{k}_{\text {ass }}$ for the interaction of porcine $\alpha_{1}$-proteinase inhibitor with various proteinases $\left(25^{\circ} \mathrm{C}, \mathrm{pH}\right.$ 8.0) measured and calculated according to Beatty et al. (19).

\begin{tabular}{|c|c|c|c|c|c|c|}
\hline \multirow{2}{*}{$\begin{array}{l}\text { Enzyme } \\
\text { Trypsin, porcine }\end{array}$} & \multicolumn{2}{|c|}{$\begin{array}{l}\text { Final } \\
\text { concentration }\end{array}$} & \multirow{2}{*}{$\begin{array}{l}\text { Substrate } \\
\text { BzArgNan }\end{array}$} & \multicolumn{2}{|l|}{$\begin{array}{l}\text { Final } \\
\text { concentration }\end{array}$} & \multirow{2}{*}{$\frac{\mathrm{k}_{\mathrm{ass}}}{\left(1 \times \mathrm{mol}^{-1} \times \mathrm{s}^{-1}\right)}$} \\
\hline & 100 & $\mathrm{nmol} / \mathrm{l}$ & & $0.8 \mathrm{mmol} / 1$ & & \\
\hline Chymotrypsin. bovine & 9 & $\mathrm{nmol} / \mathrm{l}$ & Suc(Ala) ${ }_{2}$ ProPheNan & $0.5 \mathrm{mmol} / 1$ & :s & $1.5 \times 10^{6}$ \\
\hline Thrombin, bovine & 11 & $\mu \mathrm{mol} / \mathrm{l}$ & TosGlyProArgNan & $0.7 \mathrm{mmol} / \mathrm{l}$ & 1 & $1.1 \times 10^{2}$. \\
\hline Plasmin, bovine & 0.83 & $\mu \mathrm{mol} / \mathrm{l}$ & DValLeuLysNan & $0.6 \mathrm{mmol} / \mathrm{l}$ & & $6.7 \times 10^{2}$ \\
\hline Acrosin, boar & 75 & $\mathrm{nmol} / \mathrm{l}$ & BzArgNan & $0.8 \mathrm{mmol} / \mathrm{l}$ & & $3.2 \times 10^{4}$ \\
\hline Pancreatic elastasc, porcine & 20 & $\mathrm{nmol} / \mathrm{l}$ & $\operatorname{Suc}(\mathrm{Ala})_{3} \mathrm{Nan}$ & $1 \mathrm{mmol} / 1$ & & $9.3 \times 10^{4}$ \\
\hline Leukocyte elastasc, porcine & 50 & $\mathrm{nmol} / \mathrm{l}$ & MeOSuc(Ala $)_{2}$ ProValNan & $\mathrm{mmol} / 1$ & & $1.1 \times 10^{6}$ \\
\hline
\end{tabular}

\section{Kinetic properties}

For the inhibition of porcine trypsin by porcine $\alpha_{1}$ proteinase inhibitor a specific inhibitory activity of $1.62 \mathrm{IU} / \mathrm{mg}$ was obtained. The association rate constants obtained for the inhibition of various serine proteinases by $\alpha_{1}$-proteinase inhibitor are summarized in table 3 .

\section{Immunological properties}

In immunoelectrophoresis of $\alpha_{1}$-proteinase inhibitor with porcine plasma for comparison, and in rocket immunoelectrophoresis (fig. 5), $\alpha_{1}$-proteinase inhibitor proved to be homogeneous.

\section{A B C}

Fig. 5. Rocket immunoelectrophoresis of $\alpha_{1}$-proteinase inhibitor. The agarose gel contained $2 \%(v / v)$ rabbit antiserum against whole porcine serum. Immunoelectrophoresis was done at $80 \mathrm{~V}$ and $10 \mathrm{~mA}$ for $16 \mathrm{~h}$ in $0.1 \mathrm{~mol} / \mathrm{l}$ sodium barbital, pH 8.6 .

$\alpha_{1}$-proteinase inhibitor concentrations: A, $5 \mu \mathrm{g} ; \mathrm{B}, 2.5$ $\mu \mathrm{g}$ and $\mathrm{C}, 1.25 \mu \mathrm{g}$.

\section{Discussion}

Human $\alpha_{1}$-proteinase inhibitor has attracted the interest of biochemists, molecular and cell biologists, scientists engaged in genetics as well as clinicians for many years (for reviews, see 1. c. $3,9,26,27$ ). It is surprising, therefore, that only recently methods have been published for the relatively rapid isolation of pure human $\alpha_{1}$-proteinase inhibitor in native and stable form (28). We used a combination of the various steps described formerly for the purification of porcine $\alpha_{1}$-proteinase inhibitor which, to our best knowledge, has not previously been obtained in homogeneous form. In addition to the removal of albumin, which is present in appreciable amounts in commercially available human $\alpha_{1}$-proteinase inhibitor samples, the final step of chromatography on zinc chelate-Sepharose under mild conditions (28) proved most efficaceous for producing a highly active and stable preparation (cf. tab. 1 and Results).

The described purification protocol enabled us to isolate porcine $\alpha_{1}$-proteinase inhibitor in a degree of purity close to $99 \%$, as judged by the following analyses:

(i) Sodium dodecylsulphate electrophoresis showed only one band with the expected molecular mass (fig. 3).

(ii) In isoelectric focusing all protein bands assembled around pH 4 (fig. 4) as in the case of human $\alpha_{1}$ proteinase inhibitor (27). This microheterogeneity of $\alpha_{1}$-proteinase inhibitor is well known and at least partly due to differences in the carbohydrate chains, especially in the sialic acid content of the inhibitor molecules (10).

(iii) Amino terminal end group analysis by a very sensitive and sophisticated quantitative method failed to detect any amino acid in an amount corresponding (on a molar basis) to more than 1\% of the applied $\alpha_{1}$-proteinase inhibitor preparation. This could be explained by the presence of glutamic acid in the 
native molecule, in analogy to human $\alpha_{1}$-proteinase inhibitor, which is converted to pyroglutamic acid during isolation without affecting the inhibitory properties. Amino terminal pyroglutamic acid is not cleaved off by the Edman degradation, which therefore fails to detect an amino terminal residue. An exactly similar observation has been reported for human $\alpha_{1}$-proteinase inhibitor (10).

(iv) In immunoelectrophoresis only a single precipiting arc occurred.

The proteinases listed in table 3 indicate that the inhibition spectra of porcine $\alpha_{1}$-proteinase inhibitor and human $\alpha_{1}$-proteinase inhibitor (18) are very similar, even the association rate constants between the given proteinases and $\alpha_{1}$-proteinase inhibitor of man and pig are of the same order of magnitude. The extremely high $k_{\text {ass }}$ value of the $\alpha_{1}$-proteinase inhibitor-leukocyte elastase system of the pig suggests that, as in humans, $\alpha_{1}$-proteinase inhibitor is by far the most likely candidate for interaction with liberated lysosomal elastase. Therefore, in analogy to the situation in humans, the elastase- $\alpha_{1}$-proteinase inhibitor complex should be a suitable indicator of the inflammatory response in pigs.

\section{Acknowledgement}

This work was supported in part by Sonderforschungsbereich SFB 0207 (projects LP 19 and 28) of the University of Munich.

\section{References}

1. Heimburger, N., Haupt, H. \& Schwick, H. (1971) Proc. Int. Res. Conf. Proteinase Inhibitors, 1. st. 1970, pp. 1-21.

2. Kress, L. F. \& Laskowski, M., sr. (1974) In: Proteinase Inhibitors (Fritz, H., Tschesche, H., Greene, L. J. \& Truscheit, E., eds.) pp. 23-30.

3. Travis, J. \& Salvesen, G. S. (1983) Ann. Rev. Biochem. 52, $665-708$

4. Ohlsson, K. (1976) Surgery 79, 652-657.

5. Neumann, S., Hennrich, N., Günzer, G. \& Lang, H. (1983) In: Progress in Clinical Enzymology II (Goldberg, D. M. \& Werner, M., eds.), Masson Publ., New York, in press.

6. Jochum, M., Fritz, H., Duswald, K. H. \& Hiller, E. (1983) In: Selected Topics in Clinical Enzymology (Goldberg, D. \& Werner, M., eds.) pp. 85-100.

7. Jochum, M., Duswald, K. H., Dittmer, H. \& Fritz, H. (1984) In: Neue Wege in der Entzündungsdiagnostik, I. PMN-Elastase (Fritz; H., Gabl, F. \& Greiling, H., eds.) GIT-Verlag, Darmstadt.

8. Kleesiek, K., Neumann, S. \& Greiling H. (1982) Fresenius Z. Anal. Chem. 311, 434-435.

9. Jochum, M., Witte, J., Schiessler, H., Selbmann, H. V., Ruckdeschl, H. \& Fritz, H. (1981) Eur. Surg. Res. 13, 152-168.

10. Travis, J. \& Johnson, D. (1981) Meth. Enzymol. 80, $754-765$.

11. Chase, T., jr. \& Shaw, E. (1970) Meth. Enzymol. 19, 20-27.

12. Fritz, H., Trautschold, I. \& Werle, E. (1974) In: Methoden der enzymatischen Analyse (Bergmeyer, H. U., ed.) 2nd ed., pp. 1105-1122, Verlag Chemie, Weinheim.

13. Achstetter, T., Ehmann, C. \& Wolff, D. H. (1981) Arch. Biochem. Biophys. 207, 445-454.

14. Roth, M. \& Haarsma, M. (1977) In: Neue Methoden der .Gerinnungsanalyse mit chromogenen Substraten (Witt, I., ed.) pp. 91-104, Walter de Gruyter, Berlin.
15. Friberger, P. \& Knös, M. (1979) In: Chromogenic Peptide Substrates (Sculla, M. F. \& Kakkar, V. V., eds.) pp. 128-140, Churchill Livingstone

16. Müller-Esterl, W., Kupfer, S. \& Fritz, H. (1980) Hoppe Seyler's Z. Physiol. Chem. 361, 1811-1821.

17. Bieth, J., Spiess, B. \& Wermuth, C. G. (1974) Biochem. Med. 11, 350-357.

18. Beatty, K., Bieth, J. \& Travis, J. (1980) J. Biol. Chem. 255, $3931-1934$.

19. Weber, K. \& Osborne, M. (1975) In: The Proteins (Neurath, H. \& Mill, R., eds.) Vol. 1, pp. 179-223, Academic Press, New York.

20. Righetti, P. G. \& Drysdale, J. W. (1975) J. Chromatog. 98, $271-321$.

21. Weeke, B. (1973) Scand. J. Immunol. 2, Suppl. 1, 47-56.

22. Folin, O. \& Ciocalteau, V. (1927) J. Biol. Chem. 73, $627-650$.

23. Edman, P. \& Henschen, A. (1975) In: Protein Sequence Determination (Needleman, S. B., ed.) 2nd edn, pp. 232-279, Springer Verlag, Berlin.

24. Lottspeich, F. (1980) Hoppe Seyler's Z. Physiol. Chem. $361,1829-1834$.

25. Meister, A. (1965) Biochemistry of the amino acids, Vol. II. 2nd edition, Academic Press, New York.

26. Carell, R. W., Jeppsson, J. O., Laurell, C. B., Brennan, S. O., Owen, H. C., Vaughan, L. \& Boswell, D. (1982) Nature 298, 239-334.

27. Tobin, J. J. \& Hutchinson, C. S. (1982) Arch. Intern. Med. $142,1342-1348$.

28. Bell, O. \& Carrel, R. W. (1973) Nature 243, 410-411.

29. Pannell, R., Johnson, D. \& Travis, J. (1974) Biochem. 13, $5439-5445$.

30. Fiedler, F., Geiger, R., Leysath, G. \& Hirschauer, C. (1978) Hoppe Seyler's Z. Physiol. Chem. 359, 1667-1673.

Priv. Doz. Dr. Reinhard Geiger Abteilung für Klinische Chemie und Klinische Biochemie in der Chirurgischen Klinik Innenstadt der Universität München

Nußbaumstr. 20

D-8000 München 2 
